\section{Whatever happened in 1986?}

CAN you see politics in a graph? Yes, if it is a graph of French spending on civil research (see right) The 'accordion' effect, as the French say, of policy changes in 1986 and, then, 1988 cries out for explanation.

The present period is one of renewed growth after the cutbacks between 1986 and 1988, but the French research budget is only just finding a character of its own. State research spending, and how this is reflected at the laboratory bench, still bears the imprint of the exuberant policies of the young Socialist government elected in 1981 and then the sober pruning of a neo-Gaullist government that held office for two years from 1986.

But the tone of the decade as a whole is undeniably that set by the Socialist government formed by the newly elected president, François Mitterrand. In 1981, his new Minister for Research and Industry, Jean-Pierre Chevènement, organized a series of now historic colloquia (assizes) to help determine the shape of research policy, spawning radical initiatives that found their way onto the statute book in the 15 July 1982 law on the orientation and programming of science and technology research.

The government declared that civil research spending should rise to 2.5 per cent of GDP (gross domestic product) by 1985. To that end, the 1982 statute committed the government to increase the civil research budget by a remarkable average of 17.8 per cent a year and to increase the number of state-supported researchers by 4.5 per cent each year until 1985.

In 1983, Hubert Curien, the present Minister for Research and Technology (see next page) took over from Chevènement, and innovatory schemes were announced to encourage technological progress. A tax incentive scheme to promote industrial research was set up with the goal that, by 1985 , industry should contribute 1.5 per cent of GDP to research and development.

EUREKA, the now highly successful European Communities initiative to promote trans-frontier collaboration in high-

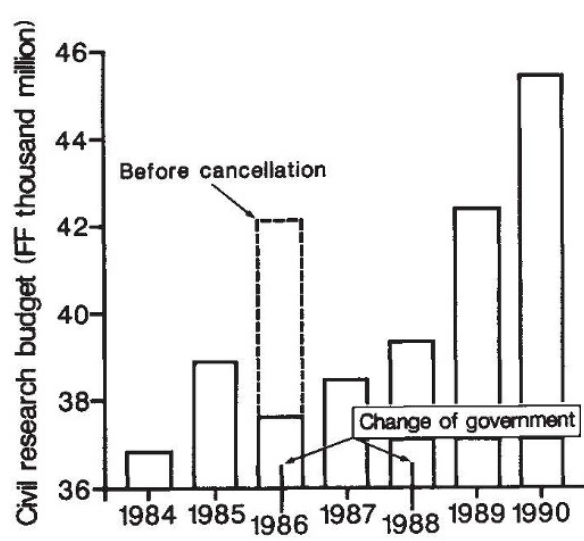

technology industry, was proposed in 1985 by Mitterrand, but it was Curien's brainchild.

It would be facile to say that this early period was uniquely good and that it came to a sudden stop when, in March 1986, the Socialists lost power. (Mitterrand remained as president, during an uneasy spell of what was called cohabitation.) But the neo-Gaullist government led by Jacques Chirac sought above all to curb public spending and to encourage the private sector to carry more of the burden of research support. The 1986 budget was annulled and the budgets of the large research organizations, such as CNRS and INSERM, virtually frozen.

Whatever the economic merits of the Chirac government's drive to streamline what it regarded as a costly and overweight public sector, those were lean

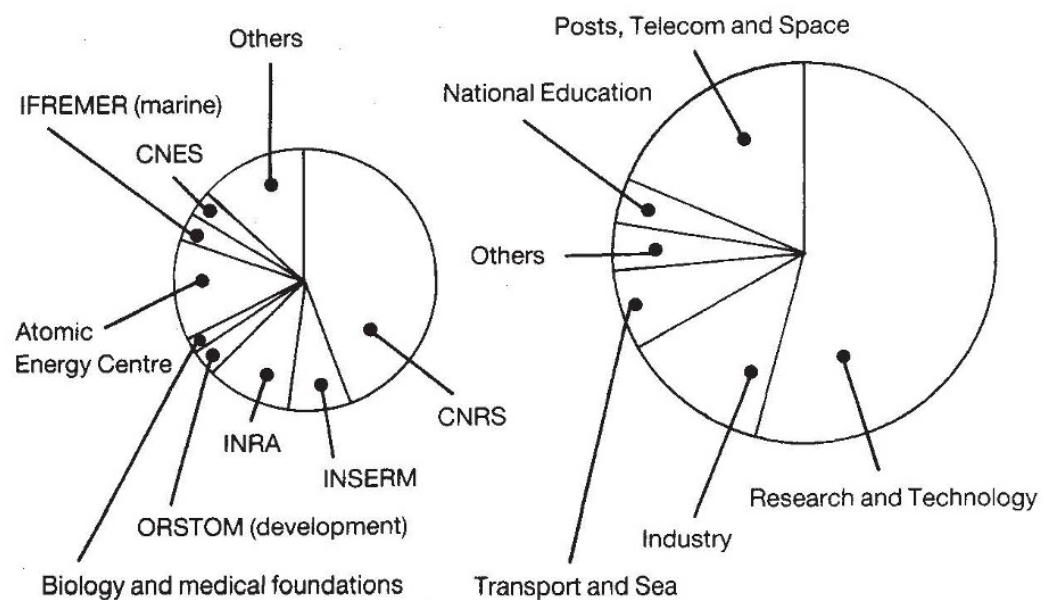

The Research and Technology Ministry receives just over half of the government's civil research budget (right). The CNRS and its institutes dominates the ministry's budget (left). years for state-supported basic research. CNRS, long regarded as a hive of leftwing trade unionists which had become too large and too powerful, was at the centre of a maelstrom.

The ministries for research and for higher education were merged under Alain Devaquet who, with encouragement from conservatives inside and outside government, launched a plan to reform CNRS. But this failed, leaving the research council's affairs in turmoil for over a year.

Devaquet resigned and was replaced by Jacques Valade, but with a much-diminished ministry; most of the budget had been handed to the minister for industry. In the event, Valade achieved little; his appointment was followed by elections which, in 1988, brought the Socialists back to power, with Michel Rocard as Prime Minister and Hubert Curien once again in charge of research.

After a short period when higher education and research were lumped together, Curien was given his own ministry of research and technology from December 1988. The civil research budget, which groups together state finance from all ministries, was reinstated - and the Chirac government was accused of budgetary deception, using defence spending to mask a fall in civil funding.

With Mitterrand once again declaring research and education national priorities, Curien was able to inject FF830 million into the research budget immediately to offset the cuts of his predecessor. The 1989 budget was up by 7.6 per cent, recruitment began again and, in the 1990 budget, salaries were improved.

But the growth in the public sector is more like half that of the pre-1985 period. Furthermore, Curien has made it clear that he wants to encourage both basic and applied research, but that big organizations such as the CNRS must run a tighter ship. A committee for evaluation has been set up and plans to 'modernize' the CNRS are under way.

At the research bench, all is not rosy. With inflation running at 3 per cent a year, the 7.3 per cent increase of the 1990 budget amounts to a more modest 4.3 per cent in real terms. The figure is even less when costly space and aeronautics, which were given a special boost, are subtracted. And, because the number of researchers has continued to rise throughout the decade, but faster than budget increases, the average scientist's research money buys almost 20 per cent less than ten years ago.

Yet the present government has not wavered in its objectives. It wants to make sure that France is well placed for the year 2000. And it now aims to see national civil research spending - hovering around 2.3 per cent of GDP - rise to 3 per cent. 